\title{
O PREQUESTIONAMENTO NO RECURSO ESPECIAL: O FUNDAMENTO JURÍDICO PARA A EXIGÊNCIA DO PREQUESTIONAMENTO NO RECURSO ESPECIAL
}

\author{
THE PREQUESTIONAMENTO AND SPECIAL FEATURE: THE LEGAL BASIS FOR THE \\ REQUIREMENT OF THE PREQUESTIONAMENTO
}

\section{Resumo}

Este estudo trata do requisito específico de admissibilidade do recurso especial que é o prequestionamento - o qual é ferramenta processual, que deve ser usado de modo objetivo, como alcance de resguardar o positivismo das leis infraconstitucionais. Temos como problemática, uma justiça que tarda é eficaz? Objetivo: O presente artigo é fruto de uma análise a fim de estudar e explicitar os meios utilizados e implantados pelas reformas processuais com intuito de alcançar a rapidez de seu trâmite e assegurar a segurança jurídica. Aspectos Metodológicos: Análise documental bibliográfica, através do método dedutivo. Revisão de Literatura: $\mathrm{O}$ artigo $5^{\circ}$, inciso LXXVIII da Constituição Federal de 1988 introduzida pela Emenda 45/04 estabelece "a todos, no âmbito judicial e administrativo, são assegurados a duração razoável do processo e os meios que garantam a celeridade de sua tramitação", juntamente à lei que alterou o Código de Processo Civil 11.419/2006 e que informatiza o processo judicial. Conforme (LOPES JÚNIOR, 2007, p. 166) "todo processo lento, é incapaz de promover a justiça". Conclusão: Logo, prequestionar até a presente data tornou-se matéria marcada por um subjetivismo inaceitável que tornará os relatores dos tribunais verdadeiros legisladores ordinários em beneficio próprios reconfigurando todo o ordenamento jurídico pátrio.

Palavras-Chave: Constituição, Prequestionamento e Recurso Especial.

\begin{abstract}
This study deals with the specific requirement of admissibility special is prequestionamento which is procedural tool that should be used in an objective way, as the reach of the laws protecting the positivism infra. We as problematic, a righteousness that is slow is effective? Objective: This article is the result of an analysis in order to study and explain the means used
\end{abstract}


and deployed by procedural reforms in order to achieve the speed of the proceeding and to ensure legal certainty. Methodological Aspects: Document analysis literature, through the deductive method. Literature Review: Article 5, paragraph LXXVIII of 1988 Constitution introduced by Amendment 45/04 states "everyone in the judicial and administrative, are assured a reasonable duration of the process and the means to guarantee the speed of its progress" along the law amending the Code of Civil Procedure 11.419/2006 and computerizing the judicial process. As (LOPES JR, 2007, p. 166) "all slow, is unable to promote justice." Conclusion: Therefore prequestionar to date became subject marked by subjectivism unacceptable that the courts will make the rapporteurs true ordinary legislators to benefit themselves by reconfiguring all the national legal system.

Keywords: Constitution, Prequestionamento and special appeal.

\section{INTRODUÇÃO}

Hodiernamente tem-se vislumbrado grandes repercussões alusivas ao prequestionamento, haja vista que o mesmo visa a buscar e a analisar a fundamentação jurídica para a existência do requisito de admissibilidade do Recurso Especial perante o Superior Tribunal de Justiça (STJ). Este requisito alvo de grandes indagações a respeito da sua efetivação legal, uma vez que este pressuposto não esta catalogado na Constituição Federal de 1988 (CF/88) e tão pouco no Código de Processo Civil (CPC), que apenas com base em súmulas e jurisprudências, faz com que este requisito torne pressuposto de admissibilidade fazendo com que a maioria de processos com recursos não cheguem à apreciação do Superior Tribunal de Justiça.

Nesse sentido, o Recurso Especial é ligado à ideia de Federalismo que este por sua vez é a união de diversos estados membros dotados de autonomia e possuem ordens regulamentadoras superiores que são as leis federais e que estas devem ser aplicadas e atuadas de forma harmônica de acordo com as competências que a Constituição Federal de 1988 as determina.

Diante da situação do entendimento unificado das leis, desde o início da construção do sistema judiciário, o direito brasileiro buscou no direito Norte Americano o Writ of error ${ }^{1}$

\footnotetext{
${ }^{1}$ Decisão sobre erro.
} 
consoante à seção 25 do Judiciary act $^{2}$ de 1789, que teria a mesma finalidade, assim surgindo o recurso extraordinário no Brasil, com a criação do decreto nº 848, de 24 de outubro de 1890.

O que antigamente era competente ao Supremo Tribunal Federal (STF) - julgar o recurso extraordinário e especial, com a vigência da Constituição Federal de 1988, a criação do Superior Tribunal de Justiça desmembrou a sua competência, que ficou a julgar recurso especial que versa sobre matéria de leis federais.

O advogado é indispensável para a administração da justiça, daí a grande responsabilidade dos mesmos, para que possam ter em seus processos a eficácia da correta aplicação do direito, com o uso de todas as "ferramentas" processuais que as leis disponibilizam em que umas destas são os Recursos, para que através destes mecanismos seja possível alcançar a justiça e haver o julgamento por um juízo ad quem ${ }^{3}$ ou pelo próprio juízo.

A fim de que o conhecimento venha a ser apreciado pelo Recurso Especial, é necessário o requisito de admissibilidade mais complexo que é o prequestionamento, no qual o entendimento deste requisito é tema de debates pelos juristas, em que para alguns doutrinadores este é ato do órgão julgador, mas para outros é necessário que o patrono instigue tal pressuposto de admissibilidade para que enfim haja apreciação do juízo competente.

A dificuldade de acesso aos tribunais excepcionais é nítida no Brasil, como é um fato notório, é dever de o Estado garantir acessibilidade aos cidadãos. O primeiro é através do poder legislativo, criando uma emenda constitucional que explicite a garantia de acesso aos recursos excepcionais, divulgando o entendimento do requisito do prequestionamento de forma clara e estabelecendo um conceito ou regulamento no código de processo civil. Segundo, os profissionais do direito devem ser preparados, para enfrentar entendimentos dos magistrados, instigando o prequestionamento, pois não há uma uniformidade do entendimento do que venha a ser tal tema e sua configuração, situação que abre precedente de subjetividade do magistrado na sua apreciação.

A questão subjetiva do prequestionamento causa aos cidadãos insegurança jurídica na correta aplicação das leis federais, deixando o direito vulnerável. Para tanto, as questões que nortearam e que deram a menção ao referido estudo foi o enorme número de processos que são inadmitidos pelo STJ e a pequena quantidade de julgadores que fez com que o prequestionamento se tornasse manobra do Superior Tribunal de Justiça para impedir que muitos processos

\footnotetext{
${ }^{2}$ Judiciário agir

3 a quem
} 
chegassem nesta instância? Em questões de ordem pública há necessidade do prequestionamento? O que fazer quando no acórdão do tribunal estadual, mesmo opondo embargos de declaração, se negar a apreciar a questão suscitada? A partir desta problemática, este trabalho tem o objetivo de demonstrar a dificuldade de acesso ao Superior Tribunal de Justiça, realizando um esboço histórico do surgimento do prequestionamento no ordenamento brasileiro, debater a sua finalidade e se o prequestionamento é inconstitucional ou constitucional.

\section{OS FUNDAMENTOS DA EXITÊNCIA DOS RECURSOS}

Desde os tempos antigos a legislação preocupa-se com as correções da má aplicação das leis. Os recursos traduzem a essência do homem em questionar-se, contrapor-se com decisões que lhe são desfavoráveis, de erros de interpretações ou aplicação das leis pelo judiciário. A base do recurso é a reforma de possíveis erros nas decisões ou procedimentos judiciais.

A palavra recursos vem do latim recursus, que se entende voltar atrás, retroagir, retornar, retroceder, fazer de novo um caminho. O código de processo civil brasileiro não menciona o conceito de recurso, apenas os enumeram em seu artigo 496 que são: apelação, agravo, embargos infringentes; embargos de declaração; recurso ordinário; recurso especial; recurso extraordinário; embargos de divergência em recurso especial e em recurso extraordinário.

Recursos podem ser entendidos na forma de sinônimos como de dinheiro, numerário, pecúnia, como também auxílio, proteção, ajuda, assistência, socorro, dote, habilidade, faculdade e aptidão. No entendimento técnico-processual, têm-se duas concepções, a ampla e a estrita: a ampla é o remédio jurídico que serve para proteger um direito que a parte pressupõe existir como na ação, a reconvenção, as exceções, a contestação e as medidas preventivas; a estrita é a essência do direito processual brasileiro que está à disposição das partes, de um terceiro, do Ministério Público dentro da relação jurídica, buscando a reforma, anulação ou esclarecimentos de decisões.

De fato, o importante é precisar que o recurso, tecnicamente falando, é a provocação feita pela parte (o que exclui, da conceituação de recurso, o reexame necessário - art. 475 CPC) dentro do mesmo processo e antes da formação da coisa julgada (o que exclui o mandado de segurança e a ação rescisória), com o objetivo de reforma, anulação ou integração de qualquer decisão judicial (NOGUEIRA, 2010, p. 02).

Os recursos mencionados da Constituição Federal, como o Recurso Especial e o Extraordinário, infelizmente de certa forma excluem a pretensão subjetiva do recorrente, não 
interessa os fatos e provas produzidas, no qual o objetivo dos Tribunais Excepcionais é prevaleça à interpretação do texto de lei, cujo estes recursos são chamados de "recursos de direito". O litigante faz uso do recurso para poder satisfazer seus objetivos de direito, desde o instante se tornou parte em uma lide, através de seu representante, e lógico que a decisão seja favorável a ele. Com este intuito que a sociedade possui, o legislador constituinte colocou como uma garantia fundamental na carta magna em seu artigo $5^{\circ}$, inciso LV "aos litigantes, em processo judicial ou administrativo, e aos acusados em geral são assegurados o contraditório e ampla defesa, com os meios e recursos a ela inerentes.". Portanto o Estado colocou os recursos à disposição da sociedade, para alcançarem seus direitos.

\section{ATOS do JUDICIÁRIO SUJEITOS A RECURSOS E A CLASSIFICAÇÃo dOS RECURSOS NO PROCESSO}

O pronunciamento do judiciário é catalogado no artigo 162 e 163 do Código de Processo Civil que são: sentenças, decisões interlocutórias, despachos e acórdãos. Apenas os atos dos juízes são passiveis de recursos, Atos das partes, dos auxiliares do juízo e do Ministério Público, não são passiveis de recursos, pois atos destes mencionados não podem causar comprometimento da lide.

Sentenças e decisões interlocutórias são gêneros de decisões, a diferença é que as sentenças é a pronuncia mento do entendimento do magistrado que põe fim a lide, objeto do processo, seja com resolução de mérito, ou sem resolução de mérito. Já a decisão interlocutória não tem gozo para por fim ao processo. Nos tribunais acerca de decisões possuem algumas peculiaridades, as decisões proferidas pelo membro (relator) que tenha caráter finalístico não são acórdãos e sim decisões interlocutórias, agora quando a decisão é proferida pelo colegiado é chamado de acórdão, consoante o artigo 163 do Código de Processo Civil. Exemplo: quando o Relator monocraticamente decide pela improcedência do recurso de apelação, esta decisão se tratará de interlocutória, agora se a apelação for considerada improcedente pelo colegiado, se tratará de acórdão.

Os despachos são despidos de conteúdo decisório, disso decorre que eles não estão sujeitos à preclusão, em qualquer de suas modalidades, podendo o juiz modificar, alterar ou substituir o anteriormente proferido, característica essa inocorrente do tocante às decisões 
interlocutórias e sentenças, de igual modo que os despachos não carecem de fundamentação.

Há de se ter claro que apenas as "decisões denegatórias" podem ser impugnadas através do recurso ordinário constitucional. Interpreta-se a expressão, porém, como capazes de abranger todas as decisões em que seja sucumbente o demandante. $\mathrm{O}$ recurso extraordinário só é cabível quando esgotados todos os recursos ordinários porventura admissíveis (CÂMARA, 2007, p.128).

A apelação hoje na sistemática processual brasileira é o meio pelo qual as partes tem a nova oportunidade de que haja novo julgamento, levando em consideração a nova apreciação dos fatos e provas, para que se promova o reexame da decisão de primeiro grau, sendo que este é a ultima fonte de recurso que vai reexaminar todo o processo, como se fosse o juízo de primeiro grau, antes de mais nada, é claro que não será o mesmo procedimento, não haverá outros autos, pois a relação processual já existe desde o inicio do processo com a citação da parte, a comparecer em uma lide. Apelação derivado de recurso de decisão de primeiro grau, sendo perceptivelmente a aplicação do principio do duplo grau de jurisdição, uma vez que este recurso é destinado ao juízo ad quem, que sem duvida, tal princípio é o ponto primordial dos estudos da doutrina no que tange a jurisdição científica do recurso.

A sentença é realmente ato do juiz singular, entretanto põe em termo o procedimento do juízo de primeiro grau. Pois a manifestação final do magistrado, ou seja, se a manifestação final do magistrado pusesse termo ao processo, a sentença seria irrecorrível, que resultaria à preclusão total das vias posteriores recursais, sendo que o exame da conceituação da sentença revela que esta pode ensejar a resolução de mérito ou sem a resolução de mérito.

Já o recurso adesivo não se trata de um recurso principal, e sim de um recurso acessório onde este depende do principal para que haja sua existência. Sendo este que possui índole de um recurso formulado a uma instância superior, que interessa a reforma parcial de uma sentença, ou seja, como um recurso interposto pelo recorrido contra o recorrente principal, após a fluência do prazo comum, com finalidade de obter o reexame do juízo ad quem da parte da decisão que lhe é desfavorável.

Agravo é a denominação de um gênero de recursos, sendo possível a identificação de três espécies: o agravo de instrumento, o agravo retido e o agravo interno. As duas primeiras espécies, reguladas pelos arts. 522 a 529 do CPC, são cabíveis contra decisões proferidas por juízo de primeira instância. Quanto ao agravo interno, é o recurso cabível contra decisões proferidas pelos relatores dos recursos (e processos de competência originária) nos tribunais, nas hipóteses em que a eles dá autorização para proferir decisões como juízos monocráticos (arts. 120, parágrafo único, 532, 545 e 557, § $1^{\circ}$, do CPC) (CÂMARA, 2007, p. 101).

Os embargos de declaração, recursos mais fáceis de ter os requisitos de admissibilidade, 
que são interpostos em face da sentença ou do acórdão quando estes apresentarem obscuridade, contradição ou omissão, buscando-se novo pronunciamento do juízo, afim de completá-la ou esclarecê-la. Este recurso de grande valia, uma vez que a contradição, a obscuridade ou a omissão pode causar um gravame ou prejuízo às partes interessadas, uma vez que a obscuridade e a contradição podem gerar incertezas do direito invocado, ou a incerteza que podem ser reparadas com os embargos de declaração.

Os embargos infringentes são considerados como recurso interposto em face de determinados acórdãos, quando o julgamento da apelação, os votos não são unânimes e houver a reforma da sentença, sendo que os embargos serão restritos à matéria divergente, entretanto existem algumas particularidades em que nem todo acórdão não unânime é passível do uso dos embargos infringentes e ao longo deste trabalho, explicarei como existe a ilusão dos operadores do direito quanto à questão debatida de voto divergente não configura prequestionamento pelo STJ.

Para a melhor compreensão do prequestionamento é necessário saber todas estas classificações dos recursos, pois ao longo de todos os procedimentos processuais, desde a petição inicial, ou com a contestação, até se chegar ao recurso especial e extraordinário, trata-se de um caminho e complexo, cheios de detalhes, observação e de entendimentos diversificados.

Os recursos excepcionais almejam alcançar nas decisões recorridas a reparação do direito não alcançado pelas partes do emprego do direito objetivo, ou seja, nos casos de recursos especiais quando decisões contrariar leis e tratados federais, a constituição federal nos casos de recurso extraordinário. $\mathrm{O}$ alcance dos recursos excepcionais é garantir a integridade do sistema jurídico federal e das disposições constitucionais.

Os efeitos dos recursos em regra possuem o efeito devolutivo, onde os autos depois de julgados retornam ao juízo a quo. Os efeitos suspensivos acorrem quando a decisão impede a eficácia da decisão recorrida, onde esta fica suspensa até o julgamento desta, isto ocorre nos recursos de apelação, embargos infringentes e nos embargos de declaração.

\section{PRINCÍPIOS DOS RECURSOS}

Princípios é idéia de algo que deve ser antes de tudo primordial, o ponto de partida, origem, mandamento onde todos os direitos são criados e entre ambos deve haver harmonia para 
melhor orientação e compreensão do sistema recursal brasileiro.

\subsection{Princípio do duplo grau de jurisdição}

No poder judiciário existe hierarquia sobre juízes, onde prevalece a decisão do órgão superior, a máxima do entendimento do duplo grau de jurisdição, é que "errar é humano", os erros podem acontecer em matéria de direito ou em matéria processual formal.

Este princípio decorre do entendimento do artigo $5^{\circ}$, LV, da CF/88, onde "aos litigantes, em processo judicial ou administrativo, e aos acusados em geral são assegurados o contraditório e ampla defesa, com os meios e recursos a ela inerentes." e mais adiante em seu artigo 105, incisos II e III estabelece a competência dos tribunais para julgar em grau de recursos, assim este principio torna-se uma garantia constitucional, sendo que o duplo grau de jurisdição tem seus limites, onde o processo vai chegando às instancias, até alcançar a ultima, sendo esta ultima decisão que valerá o emprego jurisdicional.

Os recursos constitucionais, ou seja, o recurso extraordinário e o recurso especial não garante o duplo grau de jurisdição, uma vez que pelas suas características a corte devolve ao tribunal apenas as questões de direito federal ou constitucional e o exame nesta instância é incompleto, modo em que afasta a apreciação de fatos e matérias relacionados às leis locais e a própria constituição. O recurso nas instâncias excepcionais que garante o duplo grau de jurisdição é o recurso ordinário, explicado sua função anteriormente, uma vez que este examina dos fatos, e a meteria, assim aplicando o duplo grau de jurisdição, pois também possui a sua fundamentação livre, comparado com o recurso de apelação.

\subsection{Princípio do devido processo legal}

O principio do devido processo legal, tem o condão de garantir aos litigantes uma decisão judicial que seja justa. Este princípio é alicerce aos demais princípios como o da publicidade dos atos processuais, a utilização de prova obtida por meio ilícito, do contraditório e do procedimento regular. Este princípio originou-se primeiramente na Magna Carta de João-Sem-Terra do ano de 1215, quando mencionado em seu artigo 39 referindo-se ao law of the land (lei da terra), que ao 
longo do tempo serviu de exemplo e sofreu varias lapidações até o surgimento da locução devido processo legal. Já a Constituição Federal brasileira mencionou o referido principio como garantia constitucional em seu artigo $5^{\circ}$, inciso LIV que "ninguém será privado da liberdade ou de seus bens sem o devido processo legal", que garante a proteção dos direitos dos cidadãos por parte do Estado à vida, liberdade e a propriedade.

\subsection{Princípio da taxatividade}

O principio da taxatividade consiste na existência da criação do recurso empregado por texto de lei federal. Com base no artigo 22, inciso I da CF/88, onde é estabelece o dever da União legislar sobre matéria processual.

O Código de Processo Civil em seu artigo 496 elenca os recursos do processo civil que são: I- apelação; II- agravo; III- embargos infringentes; IV- embargos de declaração; V- recurso ordinário; VI- recurso especial; VII- recurso extraordinário; VIII- embargos de divergência em recurso especial e em recurso extraordinário. Sendo objeto de observação e estudo o recurso especial, onde o órgão competente para julgar é Superior Tribunal de Justiça.

\subsection{Princípio da inafastabilidade da jurisdição}

Este princípio também pode ser chamado de direito de ação, princípio do livre acesso ao Judiciário ou como Pontes de Miranda assinalou, princípio da ubiquidade da Justiça. O princípio da inafastabilidade surge do entendimento do artigo $5^{\circ}$, inciso XXXV da CF/88 que preconizar que "a lei não excluirá da apreciação do Poder Judiciário lesão ou ameaça a direito;". Este princípio é usado de certa forma contra o estado em sua natureza de obrigar o estado a exercer sua função e resolver a lide posta a ele, é verdade que o judiciário é inerte, entretanto é necessário que as partes levem ao conhecimento do poder judiciário para que este aplique o poder

jurisdicional, sendo este poder tendo o a função de executar a organização do ordenamento jurídico. 


\subsection{Princípio da celeridade}

Com a emenda 45/2004 da constituição federal de 1988, trouxe uma inovação nas garantias fundamentais do direito dos cidadãos, que foi a implementação do inciso LXXVIII, “a todos, no âmbito judicial e administrativo, são assegurados a razoável duração do processo e os meios que garantam a celeridade de sua tramitação." que este garante a duração razoável do processo em sua tramitação judicial ou administrativa.

Com o requisito do prequestionamento, vai de encontro com tal principio, pois primeiramente obedecido o principio do duplo grau de jurisdição, o Superior Tribunal de Justiça não obedece com utilização do requisito do prequestionamento, sendo que este é um obstáculo para a atuação da celeridade, pois além do prequestionamento ser um requisito subjetivo, que cada entendimento dos desembargadores é diferenciado, faz com que a morosidade exista, caso o entendimento de que não há no acórdão recorrido o prequestionamento, as partes terá que se valer de outros recursos, para que assim possa a ter a via de acesso ao Superior Tribunal de Justiça.

\section{PERFIL DO SUPERIOR TRIBUNAL DE JUSTIÇA E CRIAÇÃO DO RECURSO ESPECIAL}

Com a criação da Constituição Federal de 1988, o recurso extraordinário houve ruptura. O recurso extraordinário que teve modelo no ordenamento dos tribunais excepcionais do direito norte-americano nos termos da seção 25 do Judiciary Act(ato do poder judiciário) de 1789 com base no writ of error(mandado de erro), primeiramente com o recurso extraordinário que surgiu com o Decreto 848 de 24 de outubro de 1890.

\subsection{Surgimento do STJ e do recurso especial}

Como o recurso extraordinário tinha a peculiaridade de ser exercitável em qualquer causa na qual estivesse presenta a questão federal, é compreensível que se tenha verificado um grande número de recursos distribuídos ao Supremo Tribunal Federal, problema que, por causa da demora em sua resolução, tornou-se, crônico passando a ser referido como a "crise do Supremo" (GARCIA, 2009, p. 45)

Antes da Constituição Federal de 1988 não existia recurso especial. Existia apenas o 
recurso extraordinário de competência do Supremo Tribunal Federal, que guardava a correta aplicação da Constituição Federal vigente e das normas de leis federais. Com o avento da Constituição Federal de 1988 e a criação do Superior Tribunal de Justiça, o recurso extraordinário desmembrou-se criando o recurso especial, ficando divididos também os tribunais excepcionais a competência da guarda da Constituição Federal ao STF e a competência das Leis Federais ao STJ.

Com a crise do Supremo Tribunal Federal antes da Constituição Federal de 1988 que sofria com abarrotamento de processos, pois era a ultima instância recursal, tinha a competência de julgar decisões que eram contrarias as leis federais e constitucionais. Tal crise se deu pelo fato do enorme território brasileiro, e o número grande de estados, onde STF era obrigado a prestar o poder jurisdicional posta a ele. O grande acúmulo de processos para julgar os recursos extraordinários, além do que o mesmo sempre teve o rigor em julgar o juízo de admissibilidade dos recursos, e em cada recurso não admitido ou não reconhecido, em face da decisão denegatória eram interpostos outros recursos, que eram os agravos de instrumentos, assim fazendo aumentar o número de processos. Era necessário desafogar o Supremo Tribunal Federal, buscando o cumprimento do principio da celeridade e diminuindo a morosidade dos processos.

A par disso, a estrutura do judiciário não acompanhou o desenvolvimento da sociedade, onde o mercado de trabalho, famílias, negócios jurídicos, violência, favelas, os sistemas desordenados das cidades entre outros, fez com que o número de atritos entre os direitos e deveres dos cidadãos aumentasse, sendo estes recorrendo ao poder judiciário para solucionar. O próprio código de processo civil, também possibilitou este aumento de processos, uma vez que a lei abre as portar para o acesso ao judiciário e o uso de recursos.

Assim o Supremo Tribunal Federal em busca de solucionar o grande número de processos nesta instância, achou como saída à criação de mais um tribunal, dividindo a competência, trabalhos e reduziriam de forma consideravelmente o numero de processos nesta instância. Criaram então o Superior Tribunal de Justiça com a Constituição Federal de 1988, ficando este tribunal com a competência de zelar pelo emprego do direito objetivo com a uniformização e referencia para os tribunais acerca do entendimento das leis infraconstitucionais a ser desenvolvida via recurso especial, ademais extinguiram o Tribunal Federal dos Recursos substituindo-os pelos cinco Tribunais Regionais Federais.

Houve varias criticas que atentaram os legisladores constituintes acerca da sua função como explica Garcia (2009, p.47): 
Por fim, duas décadas depois, a Constituição Federal acabou adotando a sugestão preconizada pela doutrina. Contudo, alguns autores protestaram contra a mudança, insistindo na manutenção do sistema anterior à Constituição de 1988. Argumentou-se, em síntese, que deveria existir apenas um Tribunal com finalidade de atender os reclamos da federação, e que a existência de mais um Tribunal Superior ensejaria maior morosidade do processo, pois estaria sendo criada mais uma instância recursal. Além disso, somou-se a tais argumentos o de que apenas se transferia o acúmulo de processos do Supremo Tribunal Federal para o Superior Tribunal de Justiça, o que não resolveria o problema.

\section{A CONCEITUAÇÃO E FINALIDADE DO RECURSO ESPECIAL}

A função dos recursos é o resultado do inconformismo de decisões judiciais e que a utilização destes visa à reforma ou anulação de decisões, antes que haja a formação da coisa julgada, com objetivo de se chegar à justiça entre as parte perante o poder judiciário. Afinal cada estado da federação possui um tribunal que podem ter entendimento diferente em cada matéria, por exemplo, a aplicação do direito pelo Tribunal de Justiça do Estado do Maranhão, pode ser mais rigorosa, ter entendimento diverso do Estado de Minas Gerais, e que o meio de unificar o entendimento do direito federal é com o recurso especial, julgado pelo STJ.

Podemos identificar o STJ como sendo o tribunal que aprecia causas de estrito direito, instância que tem a função de fazer a interpretação e unificar o entendimento acerca das leis infraconstitucionais, o recurso especial tem o papel de levar ao STJ temas relevantes a respeito de casos em que a lei federal é a regulamentadora, cuja decisão atingirá apenas as partes do processo e serão de referência aos demais tribunais.

A hipótese de cabimento do Recurso Especial, cujo este é limitado, significa que nem todos os processos podem chegar ao STJ, só podem chegar àqueles que estão elencadas no artigo 105, III da CF/88 que são quando a decisão recorrida: "a) contrariar tratado ou lei federal, ou negar-lhe vigência; b) julgar válido ato de governo local contestado em face de lei federal; c) der a lei federal interpretação divergente da que lhe haja atribuído outro tribunal.".

O Código de Processo Civil em seu artigo 541 apenas disciplina o procedimento do recurso especial, por isto o operador do direito tem que abster-se aos limites da constituição federal.

O recurso de estrito direito esta relacionado com o recurso especial, o STJ não discuti a 
justiça das decisões dos tribunais estaduais, pois esta ligada as características do estado federal onde, objetiva tutelar, cuidar do direito, por isso a importância de unificar o entendimento da aplicação lei federal através do Recurso Especial.

O recurso especial vem previsto especificamente na Constituição Federal/88, em seu artigo 105, inciso III:

Art. 105. Compete ao Superior Tribunal de Justiça:

$[\ldots]$

III - julgar, em recurso especial, as causas decididas, em única ou última instância, pelos Tribunais Regionais Federais ou pelos tribunais dos Estados, do Distrito Federal e Territórios, quando a decisão recorrida:

Tratar-se-á de recurso especial quando as "causas decididas", em única ou última instância, ou seja, só poderá ir ao STJ quando não couber mais nenhum recurso no Tribunal do estado, por exemplo, se a decisão da apelação caber o recurso de embargos infringentes, as vias de acesso ao recurso especial ainda não estará aberta, é necessário primeiramente esgotar as vias ordinárias para valer as vias excepcionais, que são o recurso extraordinário e o recurso especial. Entretanto, no recurso especial só podemos alegar nos casos quando a decisão recorrida houver o que esta prevista nas alíneas do inciso III do artigo 105 da CF/88 mencionados anteriormente.

Se não vejamos as alíneas da Constituição Federal de 1988:

Art. 105. Compete ao Superior Tribunal de Justiça:

$[\ldots]$

III - julgar, em recurso especial, as causas decididas, em única ou última instância, pelos

Tribunais Regionais Federais ou pelos tribunais dos Estados, do Distrito Federal e Territórios, quando a decisão recorrida:

a) contrariar tratado ou lei federal, ou negar-lhes vigência;

b) julgar válida lei ou ato de governo local contestado em face de lei federal;

c) der a lei federal interpretação divergente da que lhe haja atribuído outro tribunal.

\section{OS PRESSUPOSTOS GENÉRICOS DE ADMISSIBILIDADE DO RECURSO ESPECIAL}

A legitimidade é interpretada para propor o recurso especial consoante o artigo 499 do Código de Processo Civil, que o recurso pode ser interposto "pela parte vencida, pelo terceiro prejudicado e pelo Ministério Público". 
A parte vencida que menciona no artigo, pode ser o autor ou réu, ou mesmo o terceiro que surge no decorrer do processo até a decisão final recorrível. Sobre isso tem-se que:

Os terceiros intervenientes tratados no Capítulo VI do Título II do Livro I do Código de Processo Civil - ou seja, o opoente, o nomeado à autoria, o litisdenunciado e o chamado ao processo - que ingressam no processo também são considerados partes, pelo que têm legitimidade recursal. Do mesmo modo, assistente litisconsorcial está habilitado a recorrer. $\mathrm{O}$ assistente simples também pode recorrer, salvo nas hipóteses do artigo 53 do Código “(SOUZA, 2004, p.36)

O terceiro prejudicado terá que demonstrar o "nexo de interdependência entre o seu interesse de intervir e a relação jurídica submetida à apreciação judicial" (art. 499, § 1º CPC).

Já a legitimidade do Ministério Público para propor o recurso especial é clara, uma vez que positivado para atuar em processos mesmo quando atuar como parte ou quando no processo agi como fiscal da lei, conforme a súmula 99 do STJ que "o Ministério Público tem legitimidade para recorrer no processo que oficiou como fiscal da lei, ainda que não haja recurso da parte".

O interesse recursal é o ato de agir, a necessidade de utilizá-lo como ferramenta para reforma ou anulação da decisão recorrida, e só será utilizado caso não haja outra via recursal. Já a parte vitoriosa não terá vontade de prolongar o tempo do processo, mesmo porque não terá motivo de reformar uma decisão que já o satisfaz.

A tempestividade é requisito de admissibilidade de valia importância para os advogados que devem interpor o recurso especial no prazo de 15 dias a contar da intimação dobre o acórdão (artigo 506, III do CPC), o referido prazo esta catalogado no artigo 508 do CPC.

A publicação do acórdão tem-se que haver a parte do dispositivo do acórdão no órgão oficial, e que sintetize a solução a da ao caso pelo Tribunal (artigo 458, II c/c art. 165 do CPC). Acerca do prazo para recurso especial, cabe lembrar que a interposição de embargos de declaração que são de 05 dias, interrompe o prazo para recurso especial, mas utilização do embargo de declaração apenas para fins protelatórios, o juízo acerca disto, aplicará à parte embargante multa de não excedente a $1 \%$ sobre o valor da causa, e caso a parte reitera os embargos, a multa é elevada em até 10\% dobre o valor da causa (artigo 538, Parágrafo Único).

A adequação refere-se à próxima ferramenta a ser usada, levando em conta ao momento em que se encontra o processo, ou seja, qual é o próximo passo a ser seguindo, se é realmente a interposição do Recurso Especial.

Como assinalado anteriormente, que para a interposição do Recurso Especial é necessário que as vias ordinárias já estejam exauridas. Por exemplo, se no mesmo acórdão recorrido ainda 
exista a dependência da apreciação dos embargos de declaração, ou de embargos infringentes, até que saia a decisão dos embargos não é o momento para a interposição do recurso especial, assim como preceitua o Código de Processo Civil em seu artigo 498:

Art. 498. Quando o dispositivo do acórdão contiver julgamento por maioria de votos e julgamento unânime, e forem interpostos embargos infringentes, o prazo para recurso extraordinário ou recurso especial, relativamente ao julgamento unânime, ficará sobrestado até a intimação da decisão nos embargos.

Parágrafo único. Quando não forem interpostos embargos infringentes, o prazo relativo à parte unânime da decisão terá como dia de início aquele em que transitar em julgado a decisão por maioria de votos.

As orientações do Superior Tribunal de Justiça são no sentido de que conforme a súmula do STJ 418 “é inadmissível o recurso especial interposto antes da publicação do acórdão dos embargos de declaração sem posterior ratificação."

O preparo são as respectivas custas judiciais, onde a parte recorrente deve pagar emolumentos ao judiciário, que corresponde aos gastos que do judiciário possuem, além de matérias como papéis, energia e funcionários outras despesas, tem-se ainda as despesas com o envio ou retorno dos autos para os tribunais.

A falta de preparo resultará na deserção do pretendido recurso (artigo 511 do CPC), mesmo que o recorrente tenha todos os requisitos do recurso especial e principalmente o do prequestionamento, este que é a problemática deste trabalho cientifico, caso falte o preparo, todos os trabalhos foram em vão.

O Ministério Público, a União, os Estados, Municípios e as autarquias são isentas do recolhimento das custas (art. 511, $\S 1^{\circ}$ ). Entretanto, mesmo o recorrente recolhendo o preparo, e o tribunal verificando que o valor é insuficiente, o recorrente será intimado e terá prazo de cinco dias para juntar a diferença, caso contrário implicará na sua deserção.

A regularidade formal extraída do artigo 541 do Código de Processo Civil regulamenta a quem será interposto o recurso especial. Interposto perante o presidente ou vice-presidente do tribunal recorrido, em petições distintas como preceitua o artigo mencionado anteriormente, obvia que não será o recurso especial veiculado em mesma petição que o recurso extraordinário, que estes deveram conter os fatos e seus fundamentos do direito; a demonstração do cabimento e as razões do pedido de reforma da decisão recorrida. Ademais, NOGUEIRA (2011, p.23) complementa que "No tocante ao recurso especial fundado em divergência jurisprudencial, é indispensável, também a título de regularidade formal, o correto cotejo analítico entre os 
julgadores postos em confronto.”.

\section{PRESSUPOSTOS ESPECÍFICOS DE ADMISSIBILIDADE DO RECURSO ESPECIAL}

Para o recurso especial ser admitido, são também necessários os pressupostos específicos de admissibilidade do recurso especial que são: o prequestionamento, a matéria jurídica, o esgotamento dos recursos ordinários, a impugnação a todos os fundamentos válidos, recursos em “causas decididas”, contrariedade à norma federal, a hipótese de divergência jurisprudencial.

O prequestionamento trata-se de um requisito específico cujo este é substancial, tema complexo, que será desenvolvido em um capítulo, onde será abordado seu conceito e sua história, para melhor compreensão.

A matéria jurídica origina-se da Súmula 279 do STF, que diz "para simples reexame de prova não cabe recurso extraordinário.”. Na mesma linha de pensamento o STJ também se tem a Súmula 7, que "a pretensão de simples reexame de prova não enseja recurso especial”, como também a Súmula 5 do STJ diz que "a simples interpretação de cláusula contratual não enseja recurso especial.”.

Como mencionado nas súmulas dos tribunais excepcionais, a matéria fática, a apreciação de fatos, o reexame de provas ou a valoração desta, não é objeto de apreciação do STJ, uma vez que este é uma corte de estrito direito, apenas analisam causas, que vão de encontro com o que regulamenta o artigo 105, inciso III da Constituição Federal.

Só é possível a interposição do recurso especial quando os recursos ordinários (apelação, embargos infringentes, agravo, etc.), forem esgotados, assim sendo, formulada a Súmula 207, “é inadmissível recurso especial quando cabíveis embargos infringentes contra o acórdão proferido no tribunal de origem".

A impugnação a todos os fundamentos válidos, o recorrente deve ostentar-se ao fundamentar o recurso especial apenas nas causas em que são previstas pelas alíneas do inciso III do artigo 105 da Constituição Federal de 1988. Como dispõe a Súmula 126 do STJ que "é inadmissível recurso especial, quando o acórdão recorrido assenta em fundamentos constitucional e infraconstitucional, qualquer deles suficiente, por si só, para mantê-lo, e a parte vencida não manifesta recurso extraordinário.”.

Os recursos em "causas decididas", como dispõe o artigo 105, III da CF/88 que "em 
recurso especial, as causas decididas, em única ou última instância, pelos Tribunais...”, onde a palavra "causa" não é sinônimo de lide, ou de ação e sim no sentido de uma ação contenciosa, onde as partes buscam no poder judiciário uma prestação jurisdicional.

A contrariedade à norma federal acontece nas decisões recorridas quando esta for contraria as leis federais, pois sendo decisão contraria as leis estaduais ou municipais, estar não são passiveis de recurso especial.

O requisito específico que é a hipótese de divergência jurisprudencial como preconiza a alínea $c$ do artigo 105, III da CF/88, que diz "der a lei federal interposição divergente da que lhe haja atribuído outro tribunal", onde o legislador preocupa-se em apaziguar as decisões dos tribunais que muitas vezes divergem com as de outros estados.

\section{O PREQUESTIONAMENTO}

O prequestionamento não está expressamente prevista na Constituição Federal, este requisito vem da interpretação do artigo 105, inciso III, quando se diz "causas decididas, de única ou última instância", significar que aquilo que se quer levar para STJ discuta, já houve deliberação pelo juízo a quo, assim não sendo possível levar nova matéria a ser discutida no STJ.

Já houve grandes discussões acerca da ortografia da palavra Prequestionamento, pelo fato do prefixo pré- de não existir o hífen. Segundo a professora PIACENTINI (2011[ON-LINE]):

A regra (estabelecida em 1943) para o uso do acento agudo em tais casos - pré ou pre é a pronúncia aberta ou fechada do E. Isso significa que, quando o prefixo é tônico PRÉ -, ele se separa da palavra seguinte por hífen. Quando átono - PRE -, aglutina-se ao segundo elemento. Assim, de um lado temos pré-história, pré-estréia, pré-pago, prédatado, pré-moldar, pré-habilitar, pré-natal, pré-fabricado, pré-molar, pré-adolescente, pré-cozido, pré-olímpico, pré-coma, pré-eleitoral - para dar apenas alguns exemplos. De outro lado, encontramos predestinação, predispor, predisposição, precogitação, preconceito, prejulgar, predizer, predominar, pressupor, preordenar etc. $\mathrm{O}$ problema aparece quando não se distingue facilmente entre 'e' aberto e 'e' fechado, como em preanunciar, preaquecer ou precitado [citado anteriormente]. Não se pode esquecer que em muitas regiões do Brasil há uma predominância do timbre aberto, o que leva por conseqüência ao 'pré' tônico. Muitas pessoas, ou a maioria delas, falam por exemplo "pré-estabelecer" e "pré-condição", mas a grafia oficial é "preestabelecer" e "precondição". Sugiro que o leitor anote cinco casos, bastante comuns, de palavras habitualmente pronunciadas com som aberto mas escritas sem hífen e conseqüentemente sem acento gráfico. No período em que fazia apenas trabalho de revisão, eu mantinha bem à vista um cartãozinho com elas, quais sejam: $\mathrm{O}$ ajuste foi aceito de acordo com as condições preestabelecidas. Os fatos preexistentes não nos permitem mudar de rota.Toda sua tese foi elaborada com base em idéias preconcebidas. Está sendo minuciosamente predeterminado cada passo do plano. Serão predefinidos os termos em que faremos a negociação. 
Mas toda esta discussão já perdeu o objeto, tendo em vista que o vocábulo "prequestionamento" já se consolidou no dicionário da Academia Brasileira de Letras, isto por influência do Ministro Fontes de Alencar. Ademais são vários sentidos dado ao prequestionamento, pela doutrina e pela jurisprudência.

A primeira referência ao prequestionamento ocorreu na constituição de $1891 \mathrm{em}$ seu artigo 59, 3, § $1^{\circ}$, a, que previa o recurso "quando se questionar sobre a validade ou a aplicação de tratados e leis federais e a decisão do tribunal dos Estados forem contra ela". De acordo com a interpretação do texto constitucional, era necessário questionar sobre a validade de tratado ou lei federal e a decisão recorrida teria que ser contraria à validade de tratado ou lei federal. As constituições seguintes traziam a mesma norma e veio a ser modificada a partir da carta política de 1946, que posteriormente o prequestionamento evoluiu, as jurisprudências foram mudando, no sentido de que a decisão quando recorrida, tiver o direito federal explicito no entendimento, assim ficando o prequestionamento vinculado na decisão recorrida, não sendo momento anterior de postulação das partes.

Outros entendimentos como o prequestionamento seria a manifestação da parte nos atos processuais em instância inferior cumulada com à decisão da referia instância. Os diversos entendimentos doutrinários do que vem a ser o prequestionamento, existindo aqueles que defendem que basta a questão, o pronunciamento pelo Tribunal a quo seja mencionado no acórdão, ato do julgador, já configura o prequestionamento, outra corrente e que acredito ser a mais viável, onde prequestionamento origina-se desde a petição inicial ou com a contestação, primeiro ato das partes, provocarem os pontos atinentes ao direito federal que sejam debatidos nas decisões de ultima instancia dos tribunais, há outro entendimento que é ato das partes provocarem o respaldo legal e o órgão julgador se pronunciando a cerca da matéria levantada pela parte o prequestionamento juntamente com o órgão julgador, sendo de forma mista.

Ao legislador constituinte faltou ter precisão quando menciona no dispositivo constitucional de 1891 a palavra "questão federal", "quando se questionar sobre a validade (...)", assim ficando o texto incógnito, surgindo várias interpretações.

Quando menciona no dispositivo legal a palavra "questionar", quer dizer que se tem que haver por ato dos órgãos julgadores, mas primeiramente com a manifestação das partes nas razões recursais e que a controvérsia da matéria seja provocada de forma clara e concisa acerca do direito federal, sendo as partes responsáveis em provocar o julgador a pronunciar em suas 
decisões, relacionando os fatos com as leis infraconstitucionais e seus pedidos no recurso de apelação, para que haja coerência e lógica e assim os desembargares formularem suas decisões em cima destes resultando em um acórdão que seja passível do recurso especial, como ensina GUIMARÃES (2011, p.19-20):

\begin{abstract}
Prequestionamento é ato do órgão julgador, isto é, ele órgão julgador, tem que emitir juízo de valor, ou seja, apreciar e decidir sobre as questões constitucionais ou legais aplicadas ao caso concreto. Para satisfazer ao requisito do prequestionamento dos recursos extraordinário e especial basta que a questão constitucional ou infraconstitucional tenha sido debatida pelo acórdão recorrido, sem a necessidade de o colegiado observar se a matéria foi suscitada pelas partes nas suas razões e nas suas contrarrazões, ou seja, o órgão julgador não está obrigado a examinar e a aderir aos artigos e à legislação desenvolvida pelas partes, tampouco arrolá-las expressamente, mas está obrigado a examinar a questão nos limites da demanda, fundamentando o seu proceder de acordo com o seu livre convencimento, baseado nos aspectos pertinentes à hipótese sub judice e com a legislação que entender aplicável ao caso concreto. A abordagem da questão jurídica no acórdão pelo Tribunal de Apelação há que ser em termos suficientes claros e precisos para que seja possível aferir qual o dispositivo constitucional ou legal de que trata a questão jurídica decidida pelo Tribunal local, uma vez que o conhecimento dos recursos excepcionais não pode ficar ao sabor da capacidade intuitiva dos integrantes do colegiado.
\end{abstract}

Ressalta-se a diferença entre prequestionamento que é ato do órgão julgador combinada com a questão suscitada que é o ato das partes.

\title{
10. O PREQUESTIONAMENTO EXPLÍCITO E IMPLÍCITO
}

Antigamente existia uma corrente jurisprudencial no STJ e no STF, que exigia a menção expressa do dispositivo legal pelo tribunal de Apelação, que ao longo do tempo este entendimento das cortes excepcionais sofreu ruptura assim como demonstra o seguinte entendimento do STJ:

DIREITO CIVIL. PROCESSUAL CIVIL. RECURSO ESPECIAL. VIOLAÇÃO AO ART. 535, II, DO CPC. INDICAÇÃO GENÉRICA. DEFICIÊNCIA DE FUNDAMENTAÇÃO. SÚMULA 284/STF. PREQUESTIONAMENTO IMPLÍCITO. POSSIBILIDADE. LOCAÇÃO. FIANÇA. PRORROGAÇÃO LEGAL POR PRAZO INDETERMINADO. EXONERAÇÃO AUTOMÁTICA. IMPOSSIBILIDADE. PRECEDENTES DO STJ. DISSÍDIO JURISPRUDENCIAL. INEXISTÊNCIA. SÚMULA 83/STJ. RECURSO ESPECIAL CONHECIDO E IMPROVIDO. (AgRg no Ag 1232745/CE. Agravo regimental no Agravo de Instrumento 2009/3312343-9. 
Quando no acórdão recorrido, se os desembargadores mencionar o artigo e a lei em que foi fundamentada a matéria discutida acontece o chamado prequestionamento explícito. Agora o que se desenvolveu ao longo do tempo foi o prequestionamento implícito, que ocorre no momento em que o juízo monocrático ou o colegiado decide a matéria, seja pelo texto de lei invocado pelas partes ou por outro texto de lei entendido pelo julgador, onde muitas vezes o desembargador fica vulnerável para verificar se houve o prequestionamento, só porque não menciona o artigo da lei federal da questão suscitada, ou seja, quando os dispositivos entendidos por violados não constam no acórdão do Tribunal de Apelação, entretanto a matéria controvérsia foi decidida com base na legislação federal que se entende melhor para aplicação do caso concreto.

RECURSO ESPECIAL. PREQUESTIONAMENTO. Desnecessidade de menção expressa, pelo acórdão, do dispositivo legal que se pretende violado, bastando que a questão federal tenha sido debatida. (AgRg no Ag 34564654/PB. Agravo regimental no Agravo de Instrumento 2009/3312343-9. Relatora: Ministra Carmem Lucia. Data do Julgamento 02/08/1999)

Para o conhecimento do Recurso Especial com o prequestionamento implícito a matéria deve ser extraída do acórdão que se pretende recorrer, sobre as teses jurídicas em torno dos dispositivos legais tidos como violados, a fim de que se possa na instância ad quem abrir a discussão em determinada questão de estrito direito e conseqüentemente a correta interpretação e aplicação da lei federal.

A ausência do prequestionamento explícito, ou seja, apenas a menção do artigo da lei federal, não irá prejudicar a apreciação do Recurso Especial, assim como consolidada pelas jurisprudências a seguir do STJ em admitir o prequestionamento implícito:

AGRAVO REGIMENTAL. RECURSO ESPECIAL. ADMINISTRATIVO E PROCESSO CIVIL. PREQUESTIONAMENTO EXPLÍCITO. DESNECESSIDADE. LEI $\mathrm{N}^{\circ}$ 4.328/64 QUE ALTEROU LEI $\mathrm{N}^{\circ}$ 1.136/51. DIREITO ADQUIRIDO. INEXISTÊNCIA. PRECEDENTES. 1. É pacífico na jurisprudência desta Corte, que não é necessário o prequestionamento explícito dos dispositivos legais apontados como malferidos nas razões recursais, sendo suficiente a apreciação do tema objeto do recurso especial pelo Tribunal de origem. 2. O entendimento pacificado desta Corte teve como supedâneo as alterações introduzidas pela Lei $n^{\circ} 4.328 / 64$, que modificou a forma de pagamento das gratificações previstas na Lei $\mathrm{n}^{\circ} 1.316 / 51$, prescindindo, assim, de reexame de fatos e provas. 3. Esta Corte Superior uniformizou entendimento, segundo o qual, as alterações introduzidas pela Lei $\mathrm{n}^{\circ} 4.328 / 64$, que modificou a forma de 
pagamento das gratificações previstas na Lei $\mathrm{n}^{\circ} 1.316 / 51$, não acarretaram decesso remuneratório aos militares, em observância ao princípio da irredutibilidade vencimental. Precedentes.4. Agravo regimental improvido. (AgRg no REsp 782619/RJ. AGRAVO Regimental o Recurso Especial 2005/0154286-1. Relatora: Ministra MARIA THEREZA DE ASSIS MURA. Data do Julgamento: 27/10/2009).

\section{OS EMBARGOS DE DECLARAÇÃO PREQUESTIONADORES}

Como dito anteriormente, para se ter o acesso ao Recurso Especial é necessário o esgotamento das vias ordinárias e principalmente o requisito especifico de admissibilidade que é o prequestionamento da matéria, cujo este não acontecendo no acórdão, tem-se que buscar por meio dos embargos de declaração. Podem-se interpor embargos de declaração prequestionadores nos termos do artigo 535, incisos I e II do Código de Processo Civil, ou seja, quando no acórdão houver obscuridade, contradição ou a omissão, ou seja, quando no acórdão o tribunal não emitiu juízo de valor num determinado ponto em que se deveria manifestar sua decisão. Neste sentido é de se registrar o voto do relator Des. Rui Portanova, do Tribunal do Rio Grande do Sul no processo de n. ${ }^{\circ} 70034356493$ da comarca de origem de Caca, embargos julgado em 25/02/2010:

RELATÓRIO Des. Rui Portanova (RELATOR) Embargos de declaração interpostos contra acórdão que, a unanimidade, julgou procedente ação rescisória $\mathrm{n}^{\circ} 70022312946$ para desconstituir sentença de adoção dos filhos do segundo embargante ÉDISON, em favor da primeira embargante SUZANA. Alegaram omissão no acórdão por ausência de manifestação sobre dispositivos legais. Pediram o acolhimento dos embargos para que a matéria fosse prequestionada. É o relatório. VOTOS Des. Rui Portanova (RELATOR) No rigor, aqui não se alega omissão, contradição ou obscuridade. Os presentes embargos declaratórios levantam discussão apenas sobre o fato do acórdão não ter feito menção aos artigos da lei nos quais se baseou a sua fundamentação, dizendo qual incide ou não incide no caso. Além disso, referem as mesmas questões que já foram objeto de análise por ocasião do julgamento da ação rescisória. Mas, como se sabe, não se admite embargos de declaração apenas para fins de prequestionamento. Ademais, mesmo para fins de prequestionamento, é imprescindível a ocorrência de alguma das hipóteses do art. 535 do CPC, o que aqui inocorre. - De acordo com o(a) Relator(a). Des. Claudir Fidélis Faccenda - De acordo com o(a) Relator(a). DES. RUI PORTANOVA - Presidente Embargos de Declaração no 70034356493, Comarca de Casca: "NÃ O CONHECERAM. UNÂNIME." Julgador(a) de $1^{\circ}$ Grau: JOSE LUIZ LEAL VIEIRA

A obscuridade é algo que dificulta a compreensão da decisão enquanto a contradição é um problema de lógica, ou seja, quando a decisão disser um sim ou um não ao mesmo tempo. A omissão é uma questão complexa, porque ela depende da noção de decisão completa, mas como saber se a decisão esta completa, se o juiz não tem a obrigação de se manifestar sobre todos os argumentos e meramente sobre todos os fatos alegados pelas partes. A questão acerca da decisão está completa ou não é mais complexa na segunda instancia, tendo em vista que abrangem em 
decisão da apelação os fatos e as fundamentações das partes, cujo juiz deve resolver satisfatória a lide, mas não estão obrigados a se manifestarem sobre todos os fundamentos das partes, porém vale ressaltar que em nosso sistema recursal, os embargos de declaração têm uma função muito importante de preparar os recursos excepcionais.

Como dito anteriormente, o julgador não está obrigado a decidir conforme o entendimento do recorrente, podendo adotar outras teses de direito e razões, neste sentido o STJ expõe seu entendimento:

EDcl nos EDcl no AgRg no AGRAVO DE INSTRUMENTO No 831.942 - AL (2006/0211591-0) RELATOR: MINISTRO VASCO DELLA GIUSTINA (DESEMBARGADOR CONVOCADO DO TJ/RS) EMBARGANTE: BANCO DO BRASIL S/A ADVOGADOS: ANGELO AURELIO GONCALVES PARIZ E OUTRO(S) NELSON BUGANZA JUNIOR VALTER CARLOS MARQUES E OUTRO(S) EMBARGADO: COOPERATIVA REGIONAL DOS PRODUTORES DE AÇÚCAR E ÁlCOOL DE ALAGOAS ADVOGADOS: MARIA FERNANDA QUINTELLA BRANDÃO VILELA E OUTRO(S) RAFAEL NARITA DE BARROS NUNES E OUTRO(S) SANDALO BUENO DO NASCIMENTO FILHO EMENTA EMBARGOS DE DECLARAÇÃO NOS EMBARGOS DE DECLARAÇÃO NO AGRAVO REGIMENTAL NO AGRAVO DE INSTRUMENTO. INCIDÊNCIA DA SÚMULA 182/STJ. PREQUESTIONAMENTO DE DISPOSITIVOS CONSTITUCIONAIS. IMPOSSIBILIDADE. (EDcl nos EDcl no AgRg no Agravo de Instrumento No 831.942 - AL (2006/0211591-0) Relator: Ministro VASCO DELLA GIUSTINA. Data do Julgamento 02/02/2010)

Entretanto é necessário que as partes transijam para provocarem a discussão da matéria suscitada, mas caso não ocorra, as partes devem provocar os embargos prequestionadores, chamando os julgadores para se manifestar no ponto em que não debateram acerca da matéria posta na apelação, para que em fim seja discutido, abrindo a possibilidade do recurso especial ser conhecido com o pressuposto especifico que é o prequestionamento.

Este meio de obter o prequestionamento é um meio equivocado como leciona o doutrinador MEDINA (2009, p.246):

Esse entendimento, a nosso ver equivocado, surgiu em decorrência de errônea interpretação da Súmula 356 do Supremo tribunal Federal, do seguinte teor: "O ponto omisso da decisão, sobre o qual não foram opostos embargos declaratórios, não pode ser objeto de recurso extraordinário, por faltar o requisito do prequestionamento". Aludindo ao referido enunciado, Alfredo Buzaid, em decisão exarada em 1983, expôs que "através dos embargos declaratórios se prequestiona no Tribunal de origem a questão federal, a qual fica, portanto, ventilada, independentemente da solução dada" (grifou-se), concluindo, a seguir, que "o principio dominante é, pois, que o recurso extraordinário deve versar sobre questão que foi oportunamente suscitada e defendida nas instâncias ordinárias". Infere-se, pela lição do saudoso mestre, que seu entendimento era no sentido 
de que tão ou mais importante que a decisão que viesse a trazer em seu bojo a questão constitucional ou federal era a manifestação da parte, ou através do recurso de apelação, e.gi, ou na falta deste, através dos embargos declaratórios.

As outras decisões são invocadas na mesma orientação em sede de recurso especial, quando o exame da violação a lei federal ou quando negar-lhe a sua vigência, acontecerá de duas, uma: ou a questão é confrontada de frente pela decisão recorrida, ou a parte realiza o prequestionamento através dos embargos de declaração,

Esse entendimento encontra ressonância em várias decisões: "Ainda que o objeto da inconformação esteja no próprio acórdão recorrido, necessário se faz o seu prequestionamento explícito por meios dos embargos declaratórios". No mesmo sentido: "Quando a violação à lei federal surgir no julgamento de segundo grau, imprescindível a oposição de embargos declaratórios, ensejando ao Tribunal $a$ quo a oportunidade de manifesta-se sobre o tema". Ainda: "Mesmo quando a vulneração de dispositivo legal surge no próprio acórdão, é necessária a interpretação dos embargos de declaração para prequestionar, e se os embargos forem rejeitados não será admitido o recurso especial, impróprio falar-se em nulidade do acórdão e em violação ao art. 535, II, do Código de Processo Civil" (grifou-se). Essas decisões, exaradas recentemente, denotam que o entendimento surgido na jurisprudência na vigência da Constituição de 1946 ainda é atualmente invocado, até mesmo com certa veemência (MEDINA, 2009, p.180).

Segundo as doutrinas surgiu o entendimento de que atualmente têm-se duas formas de em embargos de declaração, que são os "esclarecedores", aqueles que pretendem deixar de forma clara, esclarecer dúvidas, obscuridades ou contradições, e os "prequestionadores", de grande valia para este estudo, a manifestar-se acerca das questões federais acórdão não ventilou, que são protocolizados com o fim específico de transparecer os óbices das Súmulas 282 e 356 do STF, entretanto o Código de Processo Civil.

Fulana X, nos autos dos embargos á execução que move contra o Banco Y, opôs embargos de declaração ao acórdão, sustentando a existência de omissão no arresto embargado, por não ter sido apreciada pelo colegiado a alegação de negativa de vigência ao art. $1^{\circ}$ da Lei 8.009,30, requerendo, em consequiência, o prequestionamento desse dispositivo. Ocorre, entretanto, que, embora não tenha havido referência expressa no acórdão embargado ao artigo $1^{\circ}$ da Lei 8.009/90, a matéria objeto da controvérsia foi examinada sob o enfoque desse dispositivo, mas à luz de outra legislação federal infraconstitucional que pareceu mais adequada ao caso concreto pelo colegiado, inexistindo, portanto, a omissão (GUIMARÃES, 2011, p. 49-50).

Cabe ressaltar quem, a interposição de Embargos Prequestionadores, com o notório interesse de obter a manifestação do órgão julgador o juízo da matéria federal não tem efeitos protelatório assim como regula a Súmula 98 do STJ: "Embargos de Declaração manifestados com notório propósito de prequestionamento não tem caráter protelatório.”. Portanto é bom mencionar a referida súmula nos embargos, pois além de suspender o prazo para interposição do recurso 
especial, caso os embargos seja considerado protelatório, evitará a parte sofrer multa com base no artigo 538, parágrafo único, do Código de Processo Civil:

Art. 538. Os embargos de declaração interrompem o prazo para a interposição de outros recursos, por qualquer das partes.

Parágrafo único. Quando manifestamente protelatórios os embargos, o juiz ou o tribunal, declarando que o são, condenará o embargante a pagar ao embargado multa não excedente de $1 \%$ (um por cento) sobre o valor da causa. Na reiteração de embargos protelatórios, a multa é elevada a até $10 \%$ (dez por cento), ficando condicionada a interposição de qualquer outro recurso ao depósito do valor respectivo.

\section{O QUE FAZER QUANDO NO ACÓRDÃO DO TRIBUNAL, MESMO COM OS EMBARgos DE DECLARAÇÃO, SE RECUSAR A APRECIAR A QUESTÃo SUSCITADA?}

Reprisando, se não houver o prequestionamento da matéria infraconstitucional, não é possível ir para o STJ com o recurso especial, entretanto, mesmo com interposição dos embargos de declaração "prequestionadores”, o tribunal não emitir juízo de valor, não decidiu, não analisou e se recusando há fazê-lo em sede deste recurso, por tanto, ainda não houve o prequestionamento da matéria infraconstitucional, a parte terá que providenciar o seguinte passo.

A parte terá que interpor recurso especial alegando que o tribunal julgou contraria a lei federa, negando-lhe vigência, com fundamento no artigo105, III, alínea a da CF/88, invocando a violação do artigo 535, I e II do Código de Processo Civil, para que o STJ anule o acórdão, e os autos após retorne à segunda instância.

Requerer que o STJ anule o acórdão anterior e que determine ao Tribunal a quo, emita juízo de valor em outro acórdão, o tema infraconstitucional suscitado pela parte nas suas razões de apelação, para que se tenha o prequestionamento.

Após os autos remetidos ao tribunal, e este emitindo juízo de valor da causa infraconstitucional, havendo o prequestionamento, a parte agora tem via de acesso ao recurso especial, agora para tratar do tema de fundo. Neste sentido o STJ já decidiu:

AgRg no RECURSO ESPECIAL No 804.035 - MG (2005/0206625-5) RELATOR: MINISTRO MAURO CAMPBELL MARQUES AGRAVANTE: MUNICÍPIO DE BELO HORIZONTE PROCURADOR: CAROLINA CARDOSO GUIMARÃES LISBOA E OUTRO(S) AGRAVADO: ANTÔNIO PINTO COELHO ADVOGADO: MARIA HELENA DE MELO CAMPOS - DEFENSORA PÚBLICA EMENTA PROCESSUAL CIVIL E TRIBUTÁRIO. AGRAVO REGIMENTAL. EXECUÇÃO 
FISCAL. NÃO-APLICAÇÃO DA LC 118/05 A FEITO EXECUTIVO AJUIZADO ANTES DE SUA VIGÊNCIA. DESPACHO QUE ORDENA A CITAÇÃO. NÃOINTERRUPÇÃO NA ESPÉCIE. AUSÊNCIA DE PREQUESTIONAMENTO. SÚMULA 282 DO STF. (AgRg no RECURSO ESPECIAL N 804.035 - MG (2005/0206625-5) Relator: Ministro Mauro Campbell Marques, Data de Julgamento 26/03/2010).

\section{O QUE FAZER QUANDO OCORRE O PREQUESTIONAMENTO NO ACÓRDÃO RECORRIDO QUESTÃO CONSTITUCIONAL E INFRACONSTITUCIONAL?}

É comum encontrarmos recursos excepcionais inadmitidos no STJ, quando no acórdão recorrido exista o prequestionamento da questão infraconstitucional e constitucional e as partes não interporem juntamente com o recurso especial o recurso extraordinário.

Este entendimento é com base na Súmula do STJ 126, que menciona: É inadmissível recurso especial quando o acórdão recorrido assenta em fundamentos constitucional e infraconstitucional e infraconstitucional, qualquer deles suficiente, por si só, para mantê-lo, e a parte vencida não manifesta recurso extraordinário.

Entretanto, é obrigatoriamente as partes interporem o recurso especial e recurso extraordinário, caso não seja interposto um dos dois recursos, o outro será inadmissível, ou seja, se no acórdão for discutido questão infraconstitucional terá via aberta ao STJ, mas se no acórdão discutir apenas questão constitucional, a parte terá via aberta apenas ao STF, agora se no acórdão o tribunal de apelação apreciou a questão constitucional e infraconstitucional terá que interpor os dois recursos. A parte terá saber se qual matéria foi prequestionada para não errar e interpuser apenas um recurso e deixar o cidadão no prejuízo.

\section{SÚMULA 282 DO STF E 320 DO STJ. RELAÇÃO ENTRE PREQUESTIONAMENTO E EXISTÊNCIA DE QUESTÃo CONSTITUCIONAL OU FEDERAL NA DECISÃo RECORRIDA}

A súmula editada pelo Supremo Tribunal Federal em 16/12/1963 de número 282 com teor: "É inadmissível o recurso extraordinário, quando não ventilada, na decisão recorrida, a questão federal suscitada" e a súmula editada pelo Superior Tribunal de Justiça de número 320 
que diz "A questão federal somente ventilada no voto vencido não atende ao requisito do prequestionamento".

Esta sumula vem da interpretação do artigo 101, III, $a$ e $b$, da Constituição Federal de 1946 que preconizava ser cabível o recurso extraordinário "quando a decisão for contrária a disponha o dispositivo desta Constituição ou a letra de tratado ou lei federal" (alínea $a$ ) e "quando se questionar sobre a validade de lei federal" (alínea $b$ ). Entende-se com o texto constitucional mencionado dois fenômenos que são: as partes questionando sobre o tema federal ou constitucional e o pronunciamento da decisão recorrida em termos do tema questionado. Assim GARCIA (2011, p.275-276)

É importante salientar que, como já se observou a jurisprudência da época, muito embora não descuidasse da atividade realizada pelas partes na instância local, exigia como elemento determinante para o cabimento do recurso extraordinário a violação à norma constitucional ou federal pela decisão recorrida. Dizia-se, então, que a questão poderia surgir "com surpresa para as partes", não obstante a ausência de provocação, e cabível seria o recurso extraordinário.

Apesar da Constituição Federal de 1988 não ter catalogado em seu texto de lei qualquer referência quanto às manifestações anterior das partes, entretanto prevaleceu a jurisprudência dos tribunais, que não tem abandonado tal fenômeno das manifestações das partes. Assim, o ministro do Superior Tribunal de Justiça, Garcia Vieira: "Na apelação, não se insurgiu contra a fixação dos honorários, portanto, não examinada pelo Tribunal de origem. $\mathrm{O}$ recorrente não prequestiona a matéria."

Ademais o Supremo Tribunal Federal entendeu que "os embargos de declaração não servem para questionar originalmente a ofensa ao texto constitucional não aventada anteriormente”. (STF. Agln. 502408-SP 1 ${ }^{\text {a }}$ T. j. 26.10.2004, rel. Min. Sepúlveda Pertence, DJ 26.11..2004, p. 20).

\section{O PREQUESTIONAMENTO EM QUESTÕES DE ORDEM PÚBLICA}

As questões de ordem pública onde envolve o direito coletivo, onde a aplicação de uma lei envolve toda uma nação em função da aplicabilidade de uma lei federal, ainda por mais importante que seja o entendimento do Superior Tribunal de Justiça é em que mesmo em questões de ordem pública deve haver o requisito do prequestionamento. 
Alguns doutrinadores defendem a ideia de que o prequestionamento não deve ser exigido em matérias de ordem pública, pelo fato do notório interesse público, é de fundamental importância diminuir a rigorosa dificuldade ao acesso aos tribunais excepcionais, uma que as leis primeiramente, vieram para regulamentar à vida da sociedade, que seja de forma harmônica.

Outros defendem cuja esta é abraçada pelo STJ de que também em questões de ordem pública deve haver o prequestionamento. Neste sentido o STJ decidiu:

É pacifico o entendimento desta Corte no sentido de que mesmo as questões de ordem pública, apreciáveis de ofício nas instâncias ordinárias, devem ser prequestionadas, para viabilizar o Recurso Especial. (AgRg no REsp 670364/PB Agravo Regimental no Recurso Especial 2004/0104333-4. Relatora: Ministra MARIA THEREZA DE ASSIS MOURA (1131) . Data do Julgamento: 24/11/2009).

\section{REFLEXO DO PREQUESTIONAMENTO NA SOCIEDADE E O PROJETO DO CÓDIGO DE PROCESSO CIVIL 166/2010}

Os aspectos do prequestionamento e seus reflexos na sociedade são notórios tanto na exigência por parte dos tribunais quanto nas questões jurídicas, políticas e econômicas.

O prequestionamento, caos histórico do poder judiciário encontram-se em lacunas desde a primeira constituição federal, passando por todas as constituições até do presente século, sendo que os legisladores que tem a competência para solucionar o espaço que a constituição dar ao poder judiciário de legislar de forma indireta com o uso do prequestionamento. A transcendência do prequestionamento instalou-se na ordem jurídica do Brasil, e entende-se em vários sentidos como "sagacidade, penetração, perspicaz, agudo, importância, imanência", empregada pelo legislador como relevância. O judiciário com o uso do prequestionamento espairece um sofismo de que está tudo correto, tudo certo, mas na verdade o desrespeito aos direitos humanos, o interesse coletivo e a segurança da ordem jurídica, ficam inseguras diante os entendimentos de desembargadores, apenas porque exigem o prequestionamento impedindo o prosseguimento do processo. De fato se o STJ não exigissem o prequestionamento, momentaneamente sofreria uma enorme demanda de processo nesta instancia excepcional, o que geraria outro problema ao judiciário, tendo que ampliar o número de desembargadores, gerando um enorme ônus ao judiciário, o que não deve ser levado em conta, pois o que é primordial é a aplicação da justiça.

Ademais, constitui um desrespeito político aos Poderes Constituídos pela Constituição, ou seja, ao principio federativo, pois legislam de forma indireta. A cerca da sociedade, esta situação 
excepcional compromete o mercado de trabalho e a perturbação notável entre o capital e trabalho.

Quanto à questão econômica da sociedade se reflete nas entidades de direito público ou de economia mista ou a grave ameaça à economia nacional, que desenvolve o setor mercantil e empresarial.

No Congresso Nacional tramita o projeto de lei que regulamenta o novo Código de Processo Civil, proposta pelo Senado Federal de autoria do senador José Sarney de número 166/201, cujo em seu texto com certeza mudará a visão do prequestionamento acerca dos julgamentos dos tribunais, que mudará o sistema processual do recurso especial, que inovará o sistema jurídico brasileiro, vejamos a seguinte redação do artigo 861 do projeto de lei ora mencionado:

Art. 861. Proferidos os votos, o presidente anunciará o resultado do julgamento, designando para redigir o acórdão o relator ou, se vencido este, o autor do primeiro voto vencedor. [...] $\S 3^{\circ} \mathrm{O}$ voto vencido será necessariamente declarado e considerado parte integrante do acórdão para todos os fins legais, inclusive de prequestionamento.

Há de se perceber que a sociedade já clama e o legislativo vem tomando ciência e respondendo de forma significante a situação jurídica em que se encontramos necessidade da mudança jurisdicional. Caso este projeto de lei venha ser aprovado, ficará mais acessível aos cidadãos.

\section{CONSIDERAÇÕES FINAIS}

É possível, após o processo de desenvolvimento de a referida pesquisa vislumbrar que o Superior Tribunal de Justiça criado da "costela" do Supremo Tribunal Federal, ficou incumbido de guardar, cuidar, zelar pelas leis infraconstitucionais, também tem o poder de revisão e cassação de decisões dos Tribunais a quo, indispensável para a uniformização, mas para se chegar ao lugar que o STJ ocupa, existe toda uma história das constituições que foram evoluindo até chegarmos onde tem sua eficácia verdadeira, porém cheias de interpretações.

O STJ controla o poder jurisdicional das matérias federais, e analisa as teses de fundamentação dos tribunais dos estados. Tribunal este que trata apenas de matérias de estrito direito.

Antes de tudo os recursos foram criados na intenção de satisfazer o inconformismo de 
decisões judiciais, levando ao juízo ad quem a possibilidade de reforma e cassação de decisões má proferida e má fundamentada, sem embasamento legal, verdadeiro, ou que fora do sentido de aplicação da lei. Os recursos excepcionais existem como ferramenta a serem usadas por seus patronos, afim de não afastar o poder jurisdicional.

Os recursos excepcionais, que sofreram influências do direito norte americano "wit of erro", adotando o requisito do prequestionamento, que é apenas entendimento dos tribunais excepcionais, oriundos de mera interpretação das lacunas dos textos constitucionais.

Para se ter a via de acesso ao Superior Tribunal Justiça, é necessário que não haja mais a possibilidade de interposição de meio recursal ou seja, que todas as vias ordinárias sejam exauridas, que todos os pressupostos específicos e genéricos estejam presentes, e caso contrario, o recurso especial não será admitido.

Ademais, quando na decisão recorrida não houver o prequestionamento da questão, é necessária a interposição de um dos embargos "prequestionadores", e a omissão persistir, o órgão julgador, se recusar a apreciar a questão, a parte interporá recurso especial, alegando a violação do artigo 530 e 535 do Código de Processo Civil, que se trata de uma lei federal, requerendo a parte que o acórdão seja cancelado, e o juízo ad quem, ordenando ao juízo a quo a manifestar-se acerca da matéria pretendida pela parte.

Acontece também que os Tribunais em suas decisões muitas vezes reconfiguram os fatos, fundamentando ficando á livre vontade do julgador, que não examina com rigor o que as partes aludem em suas razões, que muitas vezes, não manifestam como deveriam, mesmo que estes tenham o direito de se manifestarem em suas decisões bem como as partes pretenderem, pois o juiz tem seu direito de ter a fundamentação livre.

Quando na decisão recorrida houver questão federal e constitucional, é obrigado as partes interporem dois recursos, que são o extraordinário e o especial, caso a falta de um o outro não será admitido.

\section{REFERÊNCIAS}

CÂMARA, Alexandre Freitas. Lições de Direito Processual Civil. Rio de Janeiro: Lumen Juris, 2007. 
GUIMARÃES, Luiz Carlos Forguiri. O prequestionamento nos Recursos Extraordinário e Especial: A dificuldade do acesso á justiça nos tribunais brasileiros (STF/STJ). São Paulo: Letras Jurídicas, 2010.

JUSTIÇA, Superior Tribunal de. Jurisprudências. Disponível em <http://www.stj.jus.br>. Acesso em 30. Novembro. 2011.

LENZA, Pedro. Direito Constitucional Esquematizado. 12a ed. São Paulo:Saraiva, 2008.

MEDINA, José Miguel Garcia. Prequestionamento e Repercussão Geral e Outras Questões Relativas aos Recursos Especial e Extraordinário. 5a ed. São Paulo: Editora Revista dos Tribunais, 2009.

MOntenegro fILHO, Misael. Código de Processo Civil Comentado e Interpretado. São Paulo: Atlas, 2008.

NETO, Luiz Orione. Recursos Cíveis. 2a ed. São Paulo: Saraiva, 2006.

NOGUEIRA, Luiz Fernando Valladão. Recurso Especial de Acordo com as Leis 11.672/08 e 12.322/10. $2^{\text {a }}$ ed. Belo Horizonte: Del Rey, 2010.

RODRIGUES, Silvio. Direito Civil. São Paulo: Saraiva, 2003

SILVA, Bruno Mattos e. Prequestionamento, recurso especial e recurso extraordinário roteiro para a advocacia no STJ e no STF. 2. ed. Rio de Janeiro: Forense, 2003. 